\title{
Philosophy of Sport Education: Main Issues and Methodology
}

Authors' contribution:

A) conception and design of the study

B) acquisition of data

C) analysis and interpretation of data

D) manuscript preparation

E) obtaining funding

\section{Emanuele Isidori}

University of Rome, Italy

\section{KEYWORDS}

\begin{abstract}
The aim of this study is to reflect upon the main issues of the so-called philosophy of sport education, showing its methodologies and possible use in the context of sport studies. This study will begin answering two of the main questions dealing with the issues of the philosophy of sport education, that is: what are sport and its values from an educational philosophical perspective and how can we put these values into practice through a practical methodology?

The study will show that the philosophy of sport education is a human science capable of developing both a theoretical and practical knowledge very useful for physical education teachers, sport educators, athletes, and coaches. The aim of this philosophical science is to analyze and understand sport in order to give it an educational and hermeneutical sense: that is, interpreting and not merely describing sport and its complex problems, and trying to find a solution in light of a pedagogical perspective and through a reflexive methodology of intervention.

philosophy, education, sport, hermeneutics, methodology
\end{abstract}

\section{Between two philosophies}

For better defining the research field identified by the title of this article, it is necessary to develop a short and critical preliminary reflection on the relationship between philosophy, sport, and education. We can say that sport, as human practice which can (or may not) convey social and moral values and transform and change society for the better, always requires a deep critical-philosophical reading that gives it an interpretation in the framework of a set of educational meanings (Zeigler, 2010). Education is deeply connected with sport and its history; in the case of the term "physical education", this connection with a set of educational meanings is explicit and evident - at least theoretically - due to the presence of the noun "education" (Morgan, 2006). Indeed, the educational evidence we have just mentioned above is not obvious in the concept of sport; that is the reason why a critical and philosophical interpretation of sport is so fundamental for identifying the educational potential that sport as a social practice embodies (Arnold, 1997). 
Philosophical and educational reflection on sport can be carried out from two points of view, following two reflection lines typical of the philosophy of education (Fullat, 1988; Pring, 2004; Hirst \& Carr, 2005), whose research methods can be employed in the philosophy of sport education (Reboul, 1983; Isidori, 2012):

a) The theoretical-epistemological one;

b) The practical-methodological one.

These points of view are fundamental for answering two of the main questions dealing with the issues of the philosophy of sport education: what is sport and its values from an educational philosophical perspective and how can we put these values into practice through a practical methodology (Kretchmar, 2005)?

When trying to answer these two fundamental questions, the philosophy of sport education shows not only its nature as a specialized philosophy but also its main feature: to be a philosophical science capable to develop both theoretical and practical knowledge very useful for physical education teachers, sport educators, athletes, coaches, parents and all of the people who, for one reason or another, are involved in sport education everyday (Reid, 2002). This philosophical science is a theoretical and at the same time a practical science whose main aim is to analyze and understand sport in order to give it an educational sense in practice - that is, interpreting and not merely describing sport and its complex problems, and trying to find a solution in light of a pedagogical perspective and through a reflexive methodology of intervention.

To be clear, the main question from which the philosophy of sport education should start is: what is sport and what can we learn from it in terms of good values - those worthy of being learned by the new generations - which can help us live in a better society and world? The philosophy of sport education conceives of education not only as a matter that deals with the problems of teaching and learning or with school curricula where physical and sportive activities are taught and learnt. This philosophy thinks of education in a general and broad sense, i.e., in terms of formation of the whole human being without any gender difference. In this framework, education is conceived of as a continuous process of individual development and transformation in which sport as a human practice allows the person to harmonize her/his mind, body and soul and to unify her/his personal identity and selfhood within the society and its values, seen as the result of all the different types of unified human education actions.

In this sense, the concept of education that the philosophy of sport education implies seems to be very similar to the German term Bildung (holistic formation of the person); a word-concept very rich in hermeneutical and existentialist meanings that, if associated with sport, can allow for conceiving this practice as a personal experience (Erlebnis) in which one may experience values, major goods and vital life-forces and learn from this personal and at the same time communitarian experience (Reid, 2012).

Conceiving of sport education as a Bildung means for the philosophy which studies the relation between sport and education to put the person at the center of its reflections, looking at her/him as at the main and fundamental value which gives sense and meaning to sport. The person is the polar star that orients and guides sport as a human activity comprised of intentional and communicative actions towards the set of pedagogical meanings, educational goals, aims, and purposes that allows it to be a desirable value for all the humankind (Moore, 1982).

The philosophical interpretation of sport in light of a pedagogical perspective allows us to see sports and physical activities as practices able to generate educational values that give full significance and human sense to these practices themselves. The philosophy of sport education represents a special research field among the wide range interests of philosophy as a science. Its field is drawn by an intersection between different types of philosophies (mainly: theoretical philosophy, philosophy of education, moral and social philosophy). The starting point of this applied philosophy is that sport represents, first of all, both a pedagogical and educational problem for our society; that is, a problem of how to build and teach sport values and of how to put into practice all these values so that they can be shown in person's behaviors and skills. 
Maintaining that sport is, first of all, a matter to include in the field of pedagogy and education, and not in the fields of sport biomechanics, performance science or of sport medicine, the philosophy of sport education is perfectly in line with De Coubertin's thought (Olympism and sport conceived of in a broad sense is always and mainly a matter for philosophers and educators) (De Coubertin, 2000) and with a humanistic approach to this practice, the lack of which is one of the main problems of sport in contemporary society.

\section{Defining the terms}

Another fundamental question for the philosophy of sport in its form of philosophy of sport education is not only what "education" means and what connection exists between sport and education, but also what "sport" means and what kind of sport we are reflecting on and talking about. The philosophy of sport education conceives of sport in a very broad sense and within a wide range of meanings, in accordance with the definition given by the Council of Europe (COE, 2001) upon which the White Paper on Sport (EC, 2007) is based. This definition states that "all forms of physical activity which, through casual or organized participation, aim at expressing or improving physical fitness and mental well-being, forming social relationships or obtaining results in competition at all levels" have to be considered sport (art. 2a). This definition draws the lines of a philosophical reflection on sport focusing on the main set of issues that should be faced in the context of its educational and pedagogical framework. The COE's definition helps us to reduce the complex conceptual unity represented by sport in its fundamental components, namely:

1. The concept of "body" and "movement" contained in the macro-concept of "physical activity";

2. The concept of well-being seen as expression and improvement of the person conceived of as a whole and a unity of body and mind;

3. The concept of "social inclusion" as the main value inherent in the concept of "participation" and "social relationships"; values which sport, through education, should form in all the people;

4. The concept of competition seen in its components of play and game.

Each of these points can stimulate a philosophical reflection on sport as an educational matter (Feezell, 2006). Some simple questions (but very "complex" from the philosophical point of view) could, for example, be:

1. Does sport really promote a true unified body-mind education in accordance with the theory of the multiple intelligences - as theorized by Howard Gardner (1985) - and what is the risk of the "use" (and "consumption") of the body (in terms of ethical and social consequences) in high level sports, and how can we teach athletes to avoid the commoditization of their own body and to respect it and the person it embodies as well?

2. Does sport really promote well-being, and how can we teach children and youth (who will be adults) about living a healthy lifestyle starting from an early engagement in sport?

3. Is sport really an inclusive practice in which all people, without any sort of discrimination, can engage? What can we do to teach, through sport, the social values of peace, friendship, and mutual understanding among people belonging to different ethnic groups and genders?

4. How can we think of competition not as a contrast but as a cooperation, avoiding the risk that, due to the struggle of strong identities, the internal aggressiveness inside may become an external violence that destroys the internal and external (and therefore social and educational) values of sport?

From a philosophy of education point of view and in order to develop a pedagogical perspective on it, sport has to be conceived as an amusing/playful game and not as an opposition between strong identities but 
as in its true nature of agón (the word that the ancient Greeks used for sportive contests). Conceived of as an agón, sport reveals its collaborative and competitive nature as a practice in which people express themselves, their creativity, and the pursuit of a personal self-realization through the achievement of a common and shared goal in a context of peace and friendship as it should happen in an educational context (Winch \& Gingell, 2002).

\section{Sport, values, and education}

To sum up, we can define philosophy of sport education as a philosophical discourse on sport from an educational point of view: that is, studying and reflecting on the educational values this practice implies in the framework of the communitarian life and looking for the best way to put them into practice. But what is an educational value from a philosophical point of view? We can define sport value as something which is good for us and for sport in itself which respects the ethical and social principles that allow living in a democratic, fair, and just society (Arnold, 1989). A value can be considered "educational" when it helps us to learn new and good things or better improve our understanding of things.

Educational values are ideal concepts (we could say that they don't exist per se but always depend upon the context in which they are conceived of and shown) that orient our conduct, actions, and behaviors. We need the rules of sport (like other human practices) because they are directions for our conduct, actions, and behaviors. Education always shows us that the path we are following (through our way of acting) is correctly oriented towards the values we must respect.

Sport is always ambiguous in terms of transmission of values; this ambiguity makes sport a difficult concept to be defined in the framework of a rigorous and philosophical ethical discourse (Martínková \& Parry, 2011). We can identify, at least, three kinds of sport values (Isidori \& Reid, 2011):

1. Pure values;

2. Anti-values;

3. Mixed values.

The pure values of sport are the so-called positive ones; values that ensure in sport respect for the dignity of the person as a member of the human community (Simon, 2004). These values are educational par excellence and are embodied in sport as a physical, psychological, and social practice. They represent the starting point, the means, the aims, the ends, and the purpose of sport education in itself. Pure values in sport are, for example: health and wellbeing, playfulness, peace, socialization, social integration, friendship, creativity, self-improvement, active participation, self-control, etc.

With regard to the playfulness, from an educational philosophical point of view, we can say that this value represents the main component of sport and must always be stressed and promoted in all of the sports. Without playfulness, the fundamental component of sport conceived of as play and game as well, sport could not be distinguished from any other human body practice. It would lose its power to promote and implement its other recreational, therapeutic, and psychological values, which provide a foundation for the development of the social integration of persons.

The anti-values of sport are those negative values of sport that are completely antithetical or in contradiction with the previous ones. From an ethical point of view, for each pure value of sport it is possible to identify another just opposite to it. These negative values are generated by a system of transmitting sport values that is not framed in a context marked by an educational intentionality (committed to the improvement and development of the person). These anti-values show all the negative content that physical activities and the sports may have when they don't aim to contribute to the development of the persons and their peaceful co-existence in the human community. The anti-values of sport are very dangerous because they can generate violence, manipulation, narcissism, hedonism, commodification, sexism, racism, etc. 
The so-called mixed values are those values that are neutral from an ethical point of view. To be clear, these values may be pure values or anti-values. Their being depends upon the way they are shown, taught, and developed by social agencies of sport. These values can be victory, competition, performance, efficiency, health and well-being, etc.

We can take as an example of mixed value, the concepts of victory and prize. Victory could be a pure value when in the pursuit of winning one commits oneself to achieving - while respecting others - the results and prize in a competition. It becomes an anti-value when one, in the pursuit of winning at any cost, does not respect the rules, does damage to her/his opponent, or endangers her/his own health and life. The same thing could be said about the concept of competition more generally, which may be a pure value or an anti-value, depending upon the context in which it is conceived and developed. It is a pure value when it shows the commitment and pursuit of the person to achieving a goal in the context of a peaceful confrontation and contest, releasing and channeling her/his inner energies. It is an anti-value when all these energies and powers are used against others, for prevailing - in the sense of oppression - over them.

To be clear, it is always the social context of sport (the social and educational agencies) that ensures that the mixed values of this practice do not degenerate into negative values but instead turn into pure values. It is always the context, and its intention, that determine the perception (which should always be both pedagogical and educational because they are aimed at the development of the person and his/her spiritual enrichment) of the nature of sport in its different forms. We could say that sport, per se, is not a pure value (i.e. it does not generate communitarian or social values) but is a mixed one. It is always the educational perspective on this practice that makes it such a value and able to generate other fundamental values for the human beings. To say that sport is a value and promotes values is only a rhetorical discourse without any sense from a philosophical and social point of view (McFee, 2004).

From the philosophy of sport education point of view, the concept of sport is very similar to the Greek concept of phármakon, a word whose several meanings range from "poison" to "remedy", "antidote" and "cure". To be clear, sport is a phármakon because it can be "good" or "bad" - and "good" and "evil" in sport always coexist (Derrida, 1995) - and its being "good" or "bad" depends upon the context within is interpreted (and promoted) (Isidori, 2014).

This means that the meanings of sport can never be attributed a priori but in the hic et nunc (here and now) of its context. Therefore sport is neither, in itself, a positive nor a negative concept, but can be positive or negative depending upon the context of its interpretation and of its being put into practice. Sport is always an ambivalent and ambiguous concept that always implies some risks (both physical and moral) for the person, her/his own life and body (Hyland, 1990).

This is the reason why the philosophy of sport education highlights not just the importance of educating people to be responsible in sport, taking notice of all the risks and benefits this practice always implies, but also the need for helping persons to decide, after a careful evaluation, if being engaged in sport is "good" or "bad" (we could say "poisonous" or "remedial") for them and their existence and life experience as human beings.

\section{From theory to practice}

Among the system of so-called "sport sciences", the philosophy of sport education serves as a theoretical means to develop the conceptual framework for sport pedagogy, developing the critical, reflexive, and deconstructionist perspective of this science (Grupe, 1975; Isidori, 2010). The fundamental role played by philosophy as activity able to develop critical thinking in sport professionals is now fully recognized (Lyle, 2002). In a general sense, philosophy is an activity that helps human beings understand their world and seek the truth about things, facts, and actions, asking themselves why they exist and for what purpose they came into the world. Therefore, philosophy is a human activity innate in all of human beings who are eager to explain the world around them. 
Applied to the cultural context of sport, philosophy can be considered as a tool (that is a critical and reflective way of reasoning) that allows the professionals of physical activities and sport (such as athletes, coaches, educators, teachers, etc.) to examine and explore the meanings of this practice in relation to the construction of their identity as human beings and persons (Zeigler, 1977). Philosophy helps sport professionals to be aware of their role and function in this context. Starting from this "philosophical view" they can become aware of their role as educators and of their pedagogical function. The philosophy of sport education has the following practical functions:

1. It reflects on the needs and conditions for legitimacy of the concept of education through sport, demonstrating the importance of sport for every human being;

2. It studies the characteristics through which sport can be said to be educational, arguing the reasons that justify this practice in terms of a real promotion of human values and, in the case of school sport, its presence within the school curriculum in the form of physical education;

3. It researches the direct and indirect consequences of the absence of the educational and pedagogical component in the high level sports;

4. It analyzes the possible educational function of sport in society and in the school and uses it as a critical tool against the prevailing capitalistic mentality and against the crisis of values in society;

5. It makes proposals on how to develop educational activities, to promote values, social cohesion, and cultural pluralism in contemporary society through sport.

These functions identify specific areas of theoretical-methodological and empirical research for the philosophy of sport education. The main area of this philosophical research is, without a doubt, the educational values and pedagogy (Kosiewicz, 2003). The philosophy of sport education reflects on the educational values of sport on the basis of the following principles:

a) The principle that recognizes the dignity of all the human and non human beings as bearers of inalienable rights when they come to be engaged in sport. Sport is a right for all the people of the world and the right to "sport for all" must be taught and developed in the framework of a nondiscriminatory culture.

b) The principle that recognizes the capacity of all human beings to discover, through sport and the analysis of its reality and essence, educational values, which are cross-cultural and universal. In every athlete one can find a possibility and capacity to understand and accept cultural pluralism, diversity and difference (of gender, ethnicity, etc.). Philosophy of sport education posits the need for educating athletes in order to make them understand the existence of such differences.

c) The principle that affirms the importance of sport as a tool to fight oppression in whatever form it appears. The first form of oppression in sport is nowadays the risk of reducing athletes and all the people who are engaged in sport (including spectators) into commodities.

d) The principle that recognizes in each person the possibility to understand the universal values of sport starting from the analysis of her/his own existence and personal experience;

e) The fundamental principle which sees in sport a great means to educate the new generations and a tool available to every person to live a better, full, authentic and really "good" life.

f) The principle of strongly believing in the potential of sport education and training, seen as a real existential commitment that involves those who are engaged in sport or enjoy (as mere spectators) its values in the form of entertainment, and a tool able to build a better and a more democratic society. 
The philosophy of sport education always looks with optimism at the learning and educational processes that can be developed from sport and considers sport as an ideal ethical model for a better society. The philosophy of sport education is aware that sport represents a perennial philosophical and educational utopia; but it also knows that following this utopia in order to achieve it we can make progress in building a better and more just society and democracy. The philosophy of sport education considers values and ethics as the main matters of its research field (Parry, 2007). This philosophy aims at interpreting the values of sport in the framework of a more general context represented by a general axiology (system of human values and its scientific study) (McNamee, 1998). Its interpretation of these values never wants to be limited to the terms of "right" or "wrong", "correct" or "incorrect", "fair" or "unfair", "permitted" or "not permitted", etc.; that is, in terms of a sanction discourse in case of misconduct, non-respect or breaking of the rules.

This philosophy argues about sport values in terms of "possibility" and "necessity" (that is, in terms of "you can", "you ought" and "you should", for instance) and not in terms of constriction ("you must"), always giving the person the possibility of making a free choice and showing the consequences of all the possible choices one can make. The starting point of this philosophy is always the educational and pedagogical dimension. For this reason, it argues about sport values not in a prescriptive or repressive way but in an exhortative one, encouraging people to follow the right path towards sport values, which are promoted showing all the possible individual and social advantages that can derive from correct behaviors when one is engaged in sport, explaining them in terms of happiness, well-being, and improvement of social and communitarian life.

The philosophy of sport education aims at developing a critical-reflexive discourse on sport values, stressing the importance of education and of lifelong-learning and their fundamental roles in preventing incorrect behaviors in the amateur as well as high levels sports and in all types of physical activities; assuming, for instance, a not repressive but a critical-reflexive point of view on doping in sport, "deconstructing" and viewing this phenomenon in light of an interdisciplinary and humanistic approach (that is, not only in light of a mere medical and law perspective, as it usually happens).

\section{Conclusion}

To conclude, we can say that the philosophy of sport education highlights the need for a sport system focused both on education and the promotion of values; that is, the need for a social pedagogy of sport that should start in the family and in the school, informing people on the risks and benefits of sport practice in all of its forms, starting from childhood to adulthood.

A "philosopher" of sport education is aware that the possible lack of ethics and values in sport is not due to sport as a practice in itself but to external, exogenous and extrinsic factors that society is responsible for (Arnold, 1994). It must be said that the self-awareness of one's own practice and experience when engaged in sport is the fundamental condition for the understanding of sport values (Reid, 2009). In fact, without a critical reflection on this experience and without an "educator" who stimulates and guides this reflection showing all the possible educational values intrinsic in sport, it is difficult to think of sport as a tool to build and promote new values for persons. For this reason the philosophy of sport education is aimed at developing a critical-reflective methodology in children, youth and athletes so they may be helped to understand some of the pure values of sport such as peace, tolerance, intercultural dialogue, social inclusion and prevention of violence (Parry, 2012).

\section{REFERENCES}

Arnold, P.J. (1989). Democracy, education and sport. Journal of the Philosophy of Sport, 16(1), 100-110.

Arnold, P.J. (1994). Sport and moral education. Journal of Moral Education, 23(1), 75-90.

Arnold, P.J. (1997). Sport, ethics and education. London: Cassell. 
COE-The Commission of the European Union (2001). The European Sports Charter. Recommendation No. R (92) 13 REV (adopted by the Committee of Ministers on 24 September 1992 at the 480th meeting of the Ministers' Deputies and revised at their 752nd meeting on 16 May 2001).

De Coubertin, P. (2000). Olympism. Selected writings, edited by N. Müller. Lausanne: IOC.

Derrida, J. (1995). The rhetoric of drugs. In Interviews 1974-1994 (pp. 228-254). Stanford, CA: Stanford University Press.

EC-European Commission (2007). White Paper on Sport. Brussels: Commission of the European Communities.

Feezell, R. (2006). Sport, play and ethical reflection. Urbana and Chicago, IL: University of Illinois Press.

Fullat, O. (1988). Filosofía de la educación/Philosophy of education. Barcelona: Vicens-Vives.

Gardner, H.E. (1985). Frames of mind: The theory of multiple intelligences. New York: Basic books.

Grupe, O. (1975). The problem of the science of physical activity (or physical education) as a pedagogical discipline. In Haag, H. (1978). (Ed.), Sport Pedagogy. Content and Methodology (pp.11-14). Baltimore: University Park Press.

Hirst, P. \& Carr, W. (2005). Philosophy and Education. A Symposium. Journal of Philosophy of Education, 39(4), 615-632.

Hyland, D.A. (1990). Philosophy of sport. New York: Paragon House.

Isidori E. (2014). Derrida's concept about doping and its implications for sport education. In E. Isidori, J. Lopez Frias \& A. Müller (Eds), Philosophy, sport and education. International Perspectives (pp. 103-117). Viterbo: Sette Città.

Isidori, E. (2010). Deconstructing sport: when philosophy and education meet in Derrida's thought. Physical Culture and Sport. Studies and Research, 48, 15-20.

Isidori, E. (2012). Filosofia dell'educazione sportiva. Dalla teoria alla prassi/Philosophy of sport education: from theory to practice. Roma: Nuova Cultura.

Isidori, E \& Reid, H. (2011). Filosofia dello sport/Philosophy of sport. Bruno Mondadori-Perason: Milano.

Kosiewicz, J. (2003). Reflection on the pedagogy of sport. In J. Kosiewicz \& K. Obodynski (Eds), Sport in the mirror of the values (pp. 92-104). Rzeszow: European Association for the Sociology of Sport Rzeszow University.

Kretchmar, R. S. (2005). Practical Philosophy of Sport. Second edition. Champaign, IL: Human Kinetics.

Lyle, J. (2002). Sports coaching concepts: a framework for coaches' behaviour. London: Routledge.

Martínková, I. \& Parry, J. (2011). The double instrumentality in sport. Studies in Physical Culture \& Tourism, 18(1), 25-32.

McFee, G. (2004). Sport, rules and values. London: Routledge.

McNamee, M. (1998). Philosophy and physical education: analysis, epistemology and axiology. European Physical Education Review, 4(1), 75-91.

Moore, T.W. (1982). Philosophy of Education. An Introduction. London-Boston: Routledge and Kegan Paul.

Morgan, W.J. (2006). Philosophy and physical education. In D. Kirk, D. Macdonald \& M. O'Sullivan (Eds.), The Handbook of Physical Education (pp. 97-108). Thousand Oaks, CA: Sage.

Parry, J. (2007). Sport, ethos and education. In J. Parry, S. Robinson, M. Nesti \& N. Watson, Spirituality and Sport (pp. 186-200). London: Routledge.

Parry, J. (2012). The power of sport in peacemaking and peacekeeping. Sport In Society, 15(6), 775-787.

Pring, R. (2004). Philosophy of education. aims, theory, common sense and research. London-New York: Continuum.

Reboul, O. (1983). Les méthodes de la philosophie de l'éducation/The methods of the philosophy of education. Enrahonar: Quaderns de filosofia, 5(1), 85-92.

Reid, H.L. (2002). The philosophical athlete. Durham, NC: Carolina Academic Press.

Reid, H.L. (2009). Sport, philosophy, and the quest for knowledge. Journal of the Philosophy of Sport, 36(1), 40-49.

Reid, H.L. (2012). Introduction to the philosophy of sport. Lanham, MD: Rowman \& Littlefield Publishers.

Simon, R.L. (2004). Fair Play: Sports, Values, and Society. Boulder, CO: Westview Press.

Winch, C. \& Gingell, J. (2002). Key concepts in the philosophy of education. London: Routledge.

Zeigler, E.F. (1977). Physical education and sport philosophy. Englewood Cliffs, NJ: Prentice-Hall.

Zeigler, E.F. (2010). Philosophy of physical activity education (including educational sport). Victoria, BC: Trafford Publishing. 
AUTHOR'S ADDRESS: $\quad$ Emanuele Isidori

Laboratory of General Pedagogy

University of Rome "Foro Italico"

Piazza L. De Bosis, 15, 00135 Roma, Italy

E-mail: emanuele.isidori@uniroma4.it 